\author{
NANAEKE \\ Indonesian Journal of Early Childhood Education \\ Volume 2, Nomor 2, Desember 2019

\section{STRATEGI MANAJEMEN PROMOSI DALAM MENINGKATKAN JUMLAH PESERTA DIDIK PADA SATUAN PAUD} \\ Dahlia Patiung \\ Jurusan Pendidikan Islam Anak Usia Dini \\ Fakultas Tarbiyah dan Keguruan, UIN Alauddin Makassar \\ E-mail: dahliapatiung@yahoo.co.id \\ Besse Marjani Alwi \\ Jurusan Pendidikan Islam Anak Usia Dini \\ Fakultas Tarbiyah dan Keguruan, UIN Alauddin Makassar \\ E-mail: marjanialwi@gmail.com \\ Putri Magfira \\ Jurusan Pendidikan Islam Anak Usia Dini \\ Fakultas Tarbiyah dan Keguruan, UIN Alauddin Makassar \\ E-mail: Putrimgfr2903@gmail.com \\ Nur Alfiah \\ Jurusan Pendidikan Islam Anak Usia Dini \\ Fakultas Tarbiyah dan Keguruan, UIN Alauddin Makassar \\ E-mail: Nuralfiah0607@gmail.com \\ Rizqia Salsabila M. \\ Jurusan Pendidikan Islam Anak Usia Dini \\ Fakultas Tarbiyah dan Keguruan, UIN Alauddin Makassar \\ E-mail: Maharani.qia@gmail.com \\ Tuti Alawiyah \\ Jurusan Pendidikan Islam Anak Usia Dini \\ Fakultas Tarbiyah dan Keguruan, UIN Alauddin Makassar
}

\begin{abstract}
Abstrak
Penelitian ini bertujuan untuk mengetahui sistem managemen promosi yang ada di TK Amalia. Penelitian ini merupakan penelitian kualitatif jenis deskriptif dengan subjek penelitian guru dan kepada sekolah, Data dikumpulkan menggunakan wawancara. TK Amalia merupakan salah satu lembaga PAUD yang ada di Kabupaten Gowa berlokasi di BTN Tamarunang Indah 2. Lembaga PAUD ini belum memiliki media promosi yang memadai. Lembaga ini hanya menggunakan beberapa media promosi yang sesuai dengan instrumen manajemen promosi. Media promosi TK Amalia ditujukan untuk memperkenalkan lembaga PAUD ini kepada masyarakat di Kabupaten Gowa sebagai target untuk menambahkan minat para calon orang tua menyekolahkan anaknya di lembaga PAUD. TK Amalia membutuhkan media yang memadai, terutama media website, yang mampu mempresentasikan segala
\end{abstract}


keunggulan TK Amalia, bukan hanya untuk masyarakat Kabupaten Gowa namun masyarakat Indonesia yang ingin mengaksesnya.

Kata Kunci: Managemen Promosi; Media Website; Satuan PAUD

\begin{abstract}
This study aims to determine the strategy in the management of promotion to increase the number of students in the Amalia Kindergarten unit. This research is a descriptive qualitative research using miles and huberman models with the subject of teacher and school research. Data collected using interviews, Amalia Kindergarten is one of the PAUD institutions in Gowa Regency. Which is located at BTN Tamarunang Indah 2. This PAUD institution does not yet have adequate promotional media. This institution only uses a number of promotional media in accordance with promotional management instruments. The media for promoting Kindergarten Amalia is intended to introduce this PAUD institution to the community in Gowa Regency as a target to increase the interest of prospective parents of students. TK Amalia needs more effective media, especially website media, which is able to present all the advantages of TK Amalia, not only to the people of Gowa Regency but to Indonesian people who want to access it. Synergy in the use of promotional media, both print and online, will determine the extent of information distribution so that it can contribute to increasing the number of students.
\end{abstract}

Keywords: promotion management; website media; PAUD unit

\title{
PENDAHULUAN
}

Perkembangan lembaga PAUD yang berada di Kabupaten Gowa dan sekitarnya, cukup pesat perkembangannya salah satunya TK Amalia. TK Amalia merupakan TK dengan konsep pendidikan ramah anak kenyamananan akan menjadi hal penting dalam proses pembelajaran. Berdasarkan "UU sisdiknas no. 20 tahun 2003 dinyatakan bahwa pendidikan anak usia dini adalah suatu upaya pembinaan yang ditujukan kepada anak sejak lahir sampai dengan usia enam tahun yang dilakukan melalui pemberian rangsangan pendidikan untuk membantu pertumbuhan dan perkembangan jasmani dan rohani agar anak memiliki kesiapan dalam memasuki pendidikan lebih lanjut".

Anak usia dini merupakan masa golden age karena pada masa ini semua pertumbuhan dan perkembangan yang mengalami kemajuan sangat pesat. Perkembangan itu sangat penting untuk perkembangan anak di masa yang akan datang. Hambatan perkembangan di masa ini sangat berpengaruh pada perkembangan anak, oleh karena itu seluruh pihak yang terlibat dalam stimulasi perkembangan anak pada masa usia dini perlu memaksimalkan usahanya agar anak dapat bertumbuh dan berkembang sesuai dengan tuntutan perkembangannya. Perkembangan yang dimaksud mulai dari perkembangan fisik motorik, kognitif, sosial emosi, nilai agama dan moral serta bahasa dan seni. Stimulasi Pendidikan anak suai dinisangat penting dilakukan untuk perkembangan, stimulasi yang 
diperoleh sangat menentukan kualitas perkembangan anak dimasa depan ( Khadijah, 2016).

Anak merupakan subjek sekaligus objek dalam kegiatan pembelajaran. kegiatan belajar anak didik dalam mencapai suatu tujuan, yang memerlukan usaha aktif untuk mencapainya. Keaktifan anak didik tidak hanya dituntut secara fisik tetapi juga psikisnya. jika kurang aktif, maka kemungkinan besar tujuan pembelajaran tidak tercapai (M. Yusuf T., dkk, 2018). Hal ini sama halnya anak didik tidak belajar, karena tidak merasakan perubahan dalam dirinya, padahal belajar pada hakikatnya adalah perubahan yang terjadi setelah individu melakukan aktivitas belajar (Mulyasa, 2012).

Peningkaan kualitas pendidikan anak usia dini dinyatakan dalam Peraturan Pemerintah Nomor 2 Tahun 2019 yang merupakan penguatan terhadap Peraturan Presiden Nomor 59 Tahun 2017 tentang Pelaksanaan Pencapaian Tujuan Pembangunan Berkelanjutan, telah mengamanatkan penyediaan akses bagi anak laki-laki dan perempuan terhadap pendidikan anak usia dini yang berkualitas, inklusif, dan berkesetaraan dalam rangka mendukung pendidikan sepanjang hayat.

Pemasaran suatu proses sosial dan manajerial yang didalamnya individu dan kelompok mendapatkan apa yang mereka butuhkan dan inginkan dengan menciptakan, menawarkan dan mempertukarkan produk dan nilai untuk menarik konsumen (Kotler, 1997) Tujuan pemasaran yaitu mempertemukan kesamaan antara apa yang ingin dibeli pelanggan berprospek dan apa yang dijual organisasi,potensi untuk menyesuaikan jasa agar sejauh mungkin memenuhi keinginan pelanggan individual hendaknya tidak diabaikan (Usmara, 2008).

Manajemen Pemasaran adalah penganalisaan, perencanaan dan pengawasan program-program yang bertujuan menimbulkan pertukaran dengan pasar yang dituju dengan maksud untuk mencapai tujuan perusahaan. Swastha dan Handoko, (1997).

Promosi yang ada di lembaga PAUD disini lebih menekankan pada sosialisasi program dan keunggulan-keunggulan lembaga PAUD yang didirikan. Bahkan jika diwilayah tersebut lembaga PAUD masih asing bagi warga sekitar, maka promosi harus mengandung nilai-nilai edukasi, khususnya pentingnya pendidikan anak sejak dini. Dengan tersosialisasikannya program di kelembagaan PAUD, maka PAUD yang baru saja berdiri tersebut akan dikenal oleh masyarakat setempat.

Ketika seluruh komponen PAUD yang tercermin dalam visi dan misi berhasil meyakinkan para calon orang tua peserta didik dan calon peserta didik, maka manajemen pemasarn PAUD bisa disebut berhasil. Sebab, mereka telah menjatuhkan pilihannya untuk membeli jasa edukasi lembaga PAUD yang dipromosikan tersebut (Suyadi, 2011).

Promosi atau pemasaran lembaga PAUD disini lebih menekankan pada sosialisasi program dan keunggulan keunggulan lembaga PAUD yang didirikan. Bahkan jika diwilayah tersebut lembaga PAUD masih asing bagi warga, maka promosi 
harus mengandung nilai-nilai edukasi, khususnya pentingnya pendidikan anak sejak dini. Tersosialisasikannya program di kelembagaan PAUD, maka PAUD yang baru saja berdiri tersebut akan dikenal oleh masyarakat setempat. Dengan demikian, dalam promosi atau pemasaran lembaga PAUD keuntungan mateeri atau finansial hanya sekedar konsekuensi logis atau profesionalitas pengelolaan lembaga PAUD. Sedangkan penjualan berujung pada jumlah keuntungan materi tanpa mempertimbangkan kepuasan pelangan ( konsumen).

Menurut Terry (Hasibuan, 2006), pengorganisasian adalah tindakan mengusahakan hubungan-hubungan kelakuan yang efektif, sehingga mereka dapat bekerja sama secara baik, dan dengan demikian memperoleh kepuasan pribadi dalam hal melaksanakan tugas-tugas tertentu dalam kondisi lingkungan tertentu guna mencapai tujuan atau sasaran tertentu.

Managemen Promosi pada TK Amalia sangat menarik untuk diteliti karena TK ini merupakan lembaga yang cukup terkenal di Kabupaten Gowa, walaupun berada dalam lingkup perumahan, lembaga ini memiliki peserta didik yang lumayan banyak.

\section{METODE PENELITIAN}

Untuk memperoleh data dan informasi, dalam observasi penulis menggunakan metode-metode sebagai berikut : (1) Metode wawancara yaitu mengumpulkan data yang dilakukan dengan cara mengajukan pertanyaan-pertanyaan kepada kepala sekolah atau narasumber, (2) Metode pengamatan yaitu dengan cara mengamati secara langsung yang terjadi di lapangan.

Teknik pengumpulan data yang dilakukan menggunakan wawancara terstruktur, observasi dan dokumentasi. Data yang terkumpul dianalisis menggunakan teknik analisis data kualitatif model Miles dan Huberman, yakni dengan tahapan-tahapan: (1) mengumpulan data, (2) reduksi data, (3) penyajian data, (4) penarikan kesimpulan. (Miles dan Huberman, 2009).

\section{HASIL PENELITIAN}

TK Amalia merupakan salah satu lembaga PAUD yang ada di kabupaten Gowa, yang terletak di perumahan BTN Tamarunang. System managemen promosi yang digunakan TK Amalia hanyalah beberapa yang digunakan sesuai dari instrument, yaitu dengan bersosialisasi di waktu-waktu bulan Ramadhan, menggunakan brosur,sosialisasi dan spanduk. untuk media internet yang digunakan TK amalia ini hanya menggunakan aplikasi Facebook. Namun uniknya dari TK ini murid-muridnya cukup banyak, dan bahkan ada murid dari beberapa BTN luar kompleks. Tk Amalia memiliki ruang kepala sekolah, ruang kelas, ruang bermain, kantin. Walau dari bangunan yang cukup sederhana dan kecil, TK Amalia merupakan TK yang cukup terkenal di kalangan kompleks tersebut.

Permasalahan yang dihadapi lembaga sekolah ialah merancang sebuah bentuk desain untuk mempromosikan lembaga sekolahnya, menginformasikan 
kegiatan dan keunggulan dari lembaga sekolah tersebut. Managemen promosi yang diterapkan pada Tk Amalia sudah sangat baik, akan tetapi masih banyak media promosi yang belum digunakan pada Tk Amalia seperti sosial media , komuniasi visual dalam hal ini adalah media promosi yang mampu mempromosikan keunggulan TK Amalia yang tidak berfokus hanya kepada masyarakat sekitar, melainkan masyarakat Indonesia yang ingin mengaksesnya. Adapun tujuan yang lebih khusus ialah meningkatkan jumlah murid TK Amalia ditahun ajaran baru. Serta menjadikan TK Amalia sekolah yang unggul di Kabupaten Gowa. Dengan adanya media promosi ini, akan memberikan pengetahuan informasi kepada masyarakat mengenai pendidikan prasekolah khususnya TK Amalia yang akan menjadi sebuah media inforrmasi yang dapat di akses oleh semua orang, terutama calon wali murid, dan calon murid.

Managemen promosi TK Amalia Sungguminasa sudah cukup baik, dan wilayah edukasi yang kondusif. Dengan bangunan gedung milik sendiri, terdiri atas tiga ruang belajar untuk ruang kelas TK A, ruang kelas TK B dan ruang kelas KB/TPA, ruang guru, toilet, pembelajaran outdoor serta halaman bangunan yang cukup luas sebagai arena bermain dan berkreasi anak-anak. Suasananya kondusif dalam artian baik dan mendukung sebagai tempat belajar yang tenang dan nyaman.

Managemen promosi yang ada di TK Amalia menggunakan, media cetak, media online dan media komunikasi, media cetak yang digunakan itu, brosur, spanduk, sedangkan media online yang digunakan yaitu facebook, ada pula media komunikasi, seperti adanya sosialisasi yang diadakan di TK Amalia, seperti pendidikan parenting untuk para orang tua siswa, serta orang tua para calon anak didik, selain itu ada pula kerja bakti yang diadakan, guna untuk mengajak serta membangun citra TK Amalia di lingkungan masyarakat sekitar.

Menurut pendapat Suyadi (2011) yang menyatakan bahwa brosur adalah selebaran kertas yang berisi profil lembaga PAUD yang dipromosikan. Profil kelembagaan mencakup nama lembaga, visi-misi, motto, progam pembelajaran, progam tambahan, daftar tenaga kependidikan (guru), agenda, biaya pendidikan, dan lain sebagainya, yang dimana TK Amalia menggunakan brosur untuk mempromosikan.

Sosialisasi yang diterapkan TK Amalia guna mempromosikan kualitas lembaga pendidikannya sudah sangat baik, karena dengan sosialisaisi kepada sekolah dan guru dapat berinteraksi secara langsung dengan para calon orang tua peserta didik dengan berjalannya sosialisasi tersebut dapat meningkatkan minat para calon orang tua peserta didik karena dapat melihat dan mendangarkan secara langsung keunggulan dari lembaga pendidikan yang ada di TK Amalia.

\section{SIMPULAN}

Managemen promosi sangat bermanfaat untuk mengembangkan dan menyebarkan informasi mengenai lembaga pendidikan, serta dapat menambah 
jumlah minat peserta didik, penyebaran informasi tersebar luas, memudahkan para orang tua serta para calon peserta didik mudah mengakses informasi, apalagi media sosial sangat dimanfaatkan pada zaman sekarang, guna mempermudah penyebaran informasi yang ada dilembaga pendidikan,serta memanfaatkan lebih jauh lagi media teknologi utamanya media website dan media sosial lainnya. Sinergi pemanfaatan media promosi baik cetak maupun online sangat menentukan keluasan persebaran informasi sehingga dapat berkontribusi dalam menambah jumlah peserta didik.

\section{DAFTAR PUSTAKA}

Fahrurrozi, (2014). Efektivitas Strategi Product, Promotion, Price dalam Meningkatkan Image Sekolah dan Loyalitas Orang Tua Siswa PAUD (Studi Pada Lembaga Pendidikan Anak Usia Dini Islam Kota Semarang. http://eprints.walisongo.ac.id/id/eprint/3941. (diakses tanggal 19 November 2019).

Nirwana, Aditya. (2012). "Perancangan Situs Jaringan dan Media Promosi TK Al-Azhar Kids World Malang. JITIKA: Jurnal IImiah Teknologi dan Informasi Asia. Vol. 6, No. 1.

M. Yusuf T., dkk. (2018). "Manajemen Kurikulum pada Taman Kanak-Kanak Aulia Samata", Nanaeke: Indonesian Journal of Early Childhood Education. Vol. 1, No. 1.

Sakeon, Trivena \& Jantje Uhing. (2016). "Evaluasi Strategi Promosi dan Penjualan Terhadap Keunggulan Bersaing Pada PT. Astragraphia,TBK Cabang Manado". Jurnal EMBA: Jurnal Riset Ekonomi, Manajemen, Bisnis, dan Akuntansi. Vol. 4, No. 2.

Suyadi. (2001). Panduan Penelitian Tindakan Kelas. Jogjakarta: Diva Press.

Wibisono, Guntur \& Wahyu Eko Susanto. 2015. "Perancangan Website sebagai Informasi dan Promosi Batik Khas Kabupaten Kulonprogo". Evolusi: Jurnal Sains dan Manajemen, Vol. 3 No. 2.

Mubaridah, Laeli. (2016), “Managemen Pemasaran Lembaga Pendidikan Anak Usia Dini”. Tesis. Universitas Negeri Semarang.

134 NANAEKE - Indonesian Journal of Early Childhood Education, Vol. 2, No. 2, Desember 2019 